\title{
Renal Hypertrophy in Experimental Diabetes: A Comparison to Compensatory Hypertrophy
}

\author{
K. Seyer-Hansen \\ Second University Clinic of Internal Medicine, Kommunehospitalet, Aarhus, Denmark
}

Summary. The kidney growth seen after the induction of experimental diabetes in rats has been compared to the compensatory renal growth after onesided nephrectomy. After five days the kidney weight had increased from $650 \pm 15 \mathrm{mg}$ in a group of controls to $778 \pm 21 \mathrm{mg}$ in diabetic rats, and $764 \pm$ $17 \mathrm{mg}$ in unilaterally nephrectomised rats. The increased weight was in both groups reflected in an increased DNA content and increased RNA/DNA and protein/DNA ratios. In a group of rats made diabetic and nephrectomised at the same time, kidney weight increased to $953 \pm 22 \mathrm{mg}$ after five days. When rats were unilaterally nephrectomised after 20 days of untreated diabetes, compensatory growth was much more pronounced than in non-diabetic rats, kidney weight rising from $780 \pm 21$ to $1144 \pm 39 \mathrm{mg}$ in five days. Similarly, in rats with established compensatory renal hypertrophy, diabetes induced a very rapid growth of the remaining kidney $(1226 \pm 46 \mathrm{mg}$ after five days).

Key words: Diabetes, hypertrophy, kidney, nephrectomy, rat.

In 1971 Ross and Goldman [1] demonstrated, that rats with streptozotocin diabetes had larger kidneys than non-diabetic rats, and that compensatory renal hypertrophy was enhanced in diabetic rats. In a recent report [2] some of their findings have been confirmed and extended. In the present study diabetic renal hypertrophy has been compared to the classical model for renal growth, the compensatory hypertrophy after unilateral nephrectomy. The effects of superimposing one kind of hypertrophy upon the other have also been studied.

\section{Materials and Methods}

Two sets of experiment were performed. In the first one the rats were made diabetic with streptozotocin, or they were unilaterally nephrectomised, or both. All the animals were killed five days later and compared to intact controls.

In the second experiment the rats were made diabetic or nephrectomised. Twenty days later half of the diabetic rats were unilaterally nephrectomised, while half of the nephrectomised rats were made diabetic. After a further five days the rats were killed.

The animals were female Wistar rats from our own colony. In experiment 1 their initial body weight varied between 200 and $225 \mathrm{~g}$, and in experiment 2 between 180 and $200 \mathrm{~g}$. All animals had free access to food and water.

Diabetes was induced by intravenous injection of streptozotocin $(40-45 \mathrm{mg} / \mathrm{kg})$. The severity of the diabetes has a marked influence on the kidney hypertrophy in two ways. The rate of kidney growth was linearly related to the blood glucose, at least for values up to $300 \mathrm{mg} / 100 \mathrm{ml}$ [3]. Therefore only rats with a blood glucose exceeding $300 \mathrm{mg} / \mathrm{ml}$ at the termination of the experiments were included in the study. On the other hand, too severe diabetes with great loss of body weight inhibited kidney growth (Fig. 1). Based on the results shown here, an arbitrary limit for weight loss was chosen, so that rats, which had lost more than $30 \mathrm{~g}$ body weight during the experimental period were excluded.

Unilateral nephrectomy (right-sided) was performed under pentobarbital anaesthesia $(35 \mathrm{mg} / \mathrm{kg}$ ) by a dorsal approach.

At the end of the experiment rats were anaesthesised with pentobarbital, a sample for blood glucose determination taken from a tail vein, and the left 


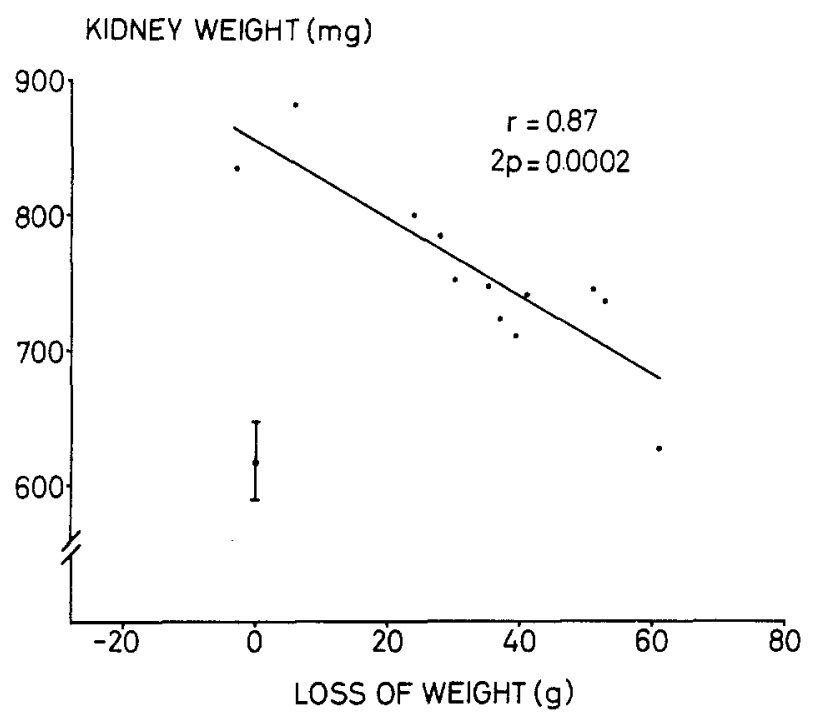

Fig. 1. The relation between kidney weight and loss of body weight in diabetic rats. All the rats weighed between 180 and $200 \mathrm{~g}$ initially and had been diabetic for 20 days. (Left kidney only)

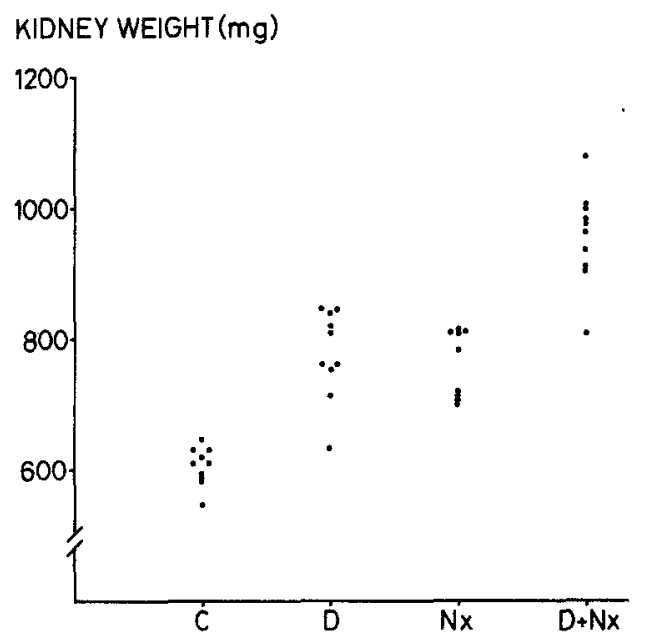

Fig. 2. Kidney weight in control rats (C), rats with diabetes for five days (D), rats five days after unilateralnephrectomy $(\mathrm{Nx})$, and rats with diabetes and nephrectomy for five days $(\mathrm{D}+\mathrm{Nx})$. (Left kidney only)

kidney removed, weighed and homogenized as described earlier [2].

RNA and DNA were separated by a SchmidtTannhäuser procedure performed according to Munro and Fleck [4]. RNA was determined by ultraviolet spectrophotometry assuming an optical density of 1.000 at $260 \mathrm{~nm}$ for an RNA concentration of $32 \mu \mathrm{g} / \mathrm{ml}$ [4]. DNA was determined with diphenylamine [5]. Protein was measured [6] using bovine serum albumin as standard. The precision of the nucleic acid determinations has been reported earlier [2].
Blood glucose was determined by a glucose oxidase method.

\section{Results}

Figure 2 and Table 1 show the kidney growth during the first five days after unilateral nephrectomy or after streptozotocin injection. The outcome of the two kinds of treatment were very similar. There was a $20 \%$ increase in wet kidney weight and a parallel rise in protein content. RNA content rose by $25 \%$, but DNA only by $10 \%$, thus the protein/DNA ratio increased by $12 \%$ and RNA/DNA by the same magnitude.

When nephrectomy and diabetes induction were performed simultaneously, the kidney growth rate more than doubled during the first five days. Wet kidney weight increased by $47 \%$ and protein content by $43 \%$. The RNA content also increased much more in these double-lesioned rats $(+53 \%)$ while the DNA content rose almost exactly as in the rats with either diabetes or nephrectomy alone.

The DNA content is an expression of the number of cells, and the protein/DNA ratio of the average cell size. Therefore it can be calculated, that the kidney growth in the diabetic and in the nephrectomised rats was due to approximately $50 \%$ hypertrophy and $50 \%$ hyperplasia. In the rats, which were both diabetic and nephrectomised, the average cell size was almost $30 \%$ greater than in the controls, and cellular hypertrophy was responsible for about $75 \%$ of the kidney growth.

Table 2 shows the effect of induction of diabetes in rats with well established compensatory renal hypertrophy 20 days after unilateral nephrectomy; and the effect of nephrectomy in 20 day - diabetic rats. At this time the kidney growth in the two groups was approaching its maximum, the kidney weight being only slightly greater than after five days. In this established state of renal hypertrophy the kidneys were somewhat larger in the nephrectomised rats than in the diabetic ones, having increased by $39 \%$ and $28 \%$, respectively, compared to the controls. The RNA/DNA and protein/DNA ratios were, however, almost identical in the two groups. The diabetic renal growth was caused by $40 \%$ hyperplasia and $60 \%$ hypertrophy, while the compensatory growth was due to $60 \%$ hyperplasia and only $40 \%$ hypertrophy.

When the diabetic rats were nephrectomised, there was a burst of renewed growth of the remaining kidney, which increased its wet weight by $50 \%$ in five days. When the nephrectomised rats were made diabetic similar kidney growth took place, amounting 
Table 1. Final body weight, kidney weight and content of protein, RNA and DNA in rats 5 days after the induction of diabetes, 5 days after unilateral nephrectomy, and 5 days after combined diabetes and nephrectomy. Values are means \pm SEM

\begin{tabular}{lrlllllll}
\hline & $\mathrm{n}$ & $\begin{array}{l}\text { Body weight } \\
(\mathrm{g})\end{array}$ & $\begin{array}{l}\text { Kidney weight } \\
(\mathrm{mg})\end{array}$ & $\begin{array}{l}\text { Protein } \\
(\mathrm{mg})\end{array}$ & $\begin{array}{l}\text { RNA } \\
(\mathrm{mg})\end{array}$ & $\begin{array}{l}\text { DNA } \\
(\mathrm{mg})\end{array}$ & $\begin{array}{l}\text { Protein/DNA } \\
(\mathrm{mg} / \mathrm{mg})\end{array}$ & $\begin{array}{l}\text { RNA/DNA } \\
(\mathrm{mg} / \mathrm{mg})\end{array}$ \\
\hline Controls & 10 & $214 \pm 2$ & $650 \pm 15$ & $80 \pm 2$ & $2.55 \pm 0.06$ & $3.50 \pm 0.07$ & $22.9 \pm 0.4$ & $0.73 \pm 0.003$ \\
Diabetes & 10 & $197 \pm 5$ & $778 \pm 21$ & $98 \pm 2$ & $3.15 \pm 0.10$ & $3.82 \pm 0.13$ & $25.6 \pm 0.6$ & $0.83 \pm 0.02$ \\
Nephrectomy & 9 & $205 \pm 5$ & $764 \pm 17$ & $100 \pm 2$ & $3.09 \pm 0.08$ & $3.87 \pm 0.10$ & $25.9 \pm 0.6$ & $0.80 \pm 0.02$ \\
Diabetes + Nx & 10 & $193 \pm 4$ & $953 \pm 22$ & $113 \pm 3$ & $3.86 \pm 0.10$ & $3.89 \pm 0.09$ & $29.2 \pm 0.4$ & $1.00 \pm 0.01$ \\
\hline
\end{tabular}

Table 2. Final body weight, kidney weight and content of protein, RNA and DNA in rats 20 days after the induction of diabetes (D-20), 20 days after unilateral nephrectomy $(\mathrm{Nx}-20) 25$ days after the induction of diabetes with unilateral nephrectomy performed after 20 days of diabetes (D-25, Nx-5), and 25 days after unilateral nephrectomy with diabetes induced 20 days after nephrectomy (Nx-25, D-5). Values are means \pm SEM

\begin{tabular}{|c|c|c|c|c|c|c|c|c|}
\hline & $\mathrm{n}$ & $\begin{array}{l}\text { Body weight } \\
\text { (g) }\end{array}$ & $\begin{array}{l}\text { Kidney weight } \\
\text { (mg) }\end{array}$ & $\begin{array}{l}\text { Protein } \\
(m g)\end{array}$ & $\begin{array}{l}\text { RNA } \\
\text { (mg) }\end{array}$ & $\begin{array}{l}\text { DNA } \\
\text { (mg) }\end{array}$ & $\begin{array}{l}\text { Protein/DNA } \\
(\mathrm{mg} / \mathrm{mg})\end{array}$ & $\begin{array}{l}\text { RNA/DNA } \\
\text { (mg/mg) }\end{array}$ \\
\hline Controls & 10 & $190 \pm 2$ & $608 \pm 9$ & $74 \pm 1$ & $2.58 \pm 0.04$ & $3.35 \pm 0.08$ & $22.1 \pm 0.4$ & $0.77 \pm 0.01$ \\
\hline D-20 & 8 & $167 \pm 6$ & $780 \pm 21$ & $101 \pm 2$ & $2.99 \pm 0.08$ & $3.68 \pm 0.12$ & $27.6 \pm 0.6$ & $0.82 \pm 0.02$ \\
\hline $\mathrm{NX}-20$ & 9 & $208 \pm 4$ & $843 \pm 10$ & $109 \pm 2$ & $3.21 \pm 0.05$ & $4.06 \pm 0.09$ & $27.1 \pm 0.3$ & $0.79 \pm 0.01$ \\
\hline $\mathrm{D}-25, \mathrm{Nx}-5$ & 9 & $170 \pm 4$ & $1144 \pm 39$ & $136 \pm 5$ & $4.18 \pm 0.34$ & $4.28 \pm 0.18$ & $31.8 \pm 0.9$ & $0.98 \pm 0.05$ \\
\hline$N x-25, D-5$ & 9 & $203 \pm 4$ & $1226 \pm 46$ & $144 \pm 7$ & $4.7 .5 \pm 0.42$ & $4.74 \pm 0.21$ & $30.5 \pm 0.6$ & $1.00 \pm 0.06$ \\
\hline
\end{tabular}

to $45 \%$. This burst of growth was also reflected in a $25 \%$ increase in the activity of the protein synthesis apparatus as expressed by the RNA/DNA ratio. About $30 \%$ of the renewed kidney growth could be accounted for by increase in cell number (DNA content), the remaining $70 \%$ being due to increased cell size.

The final outcome of this sequential induction of diabetes and nephrectomy was, that after 25 days the kidneys were $90-100 \%$ heavier than in the control rats.

\section{Discussion}

The results on the diabetic rats confirm the earlier findings [2] which showed significant kidney growth after a few days of diabetes. It is also in accordance with the previous studies, that the kidney growth is a mixture of hypertrophy and hyperplasia. This growth is not caused by streptozotocin per se, as it can be prevented by insulin administration [2].

The kidney growth rate is linearly related to the blood glucose concentration [3], but on the other hand severe hyperglycaemia with resulting loss of body weight inhibits kidney growth (Fig. 1).

In the present study, the renal growth after unilateral nephrectomy was in keeping with the results of several other investigators. The only difference being that in this study, hyperplasia was found to be the dominant component, whereas others (e.g. Kurnick and Lindsay [7]) found that hypertrophy was the major factor in renal growth. However, the two studies may not be directly comparable, because the RNA/DNA ratio in the present study was much lower than in that by Kurnick and Lindsay.

Induction of diabetes and removal of one kidney appear to stimulate kidney growth to a very similar extent (Table 1). Given together, the two stimuli have an additive effect. However, these relatively crude biochemical studies do not indicate that the two kinds of hypertrophy are identical; they may affect different anatomical structures.

When rats with established renal hypertrophy from either diabetes or unilateral nephrectomy are exposed to "the other" stimulus, the growth response is very pronounced - as if diabetes sensitises the kidney to the effects of nephrectomy, and vice versa. This phenomenon is difficult to explain.

The mechanisms behind diabetic and compensatory renal hypertrophy may well be different. Humoural renotrophic factors are probably responsible for kidney growth after unilateral nephrectomy [8]. For the diabetic kidney growth a "work load" hypothesis seems attractive, as the diabetic kidney undoubtedly has increased energy consumption due to glucose reabsorption and gluconeogenesis.

The obvious question regarding diabetic renal hypertrophy is whether or not it is of importance for the development of long-term diabetic glomerulopathy. In this connection the work of Mauer and co-workers is of great interest. They have shown, that 
the mesangial thickening and the accumulation of immunoglobulins in the glomerular mesangium seen in diabetic rats after some months, is markedly enhanced, when the diabetic animal is unilaterally nephrectomised [9]. Furthermore they have in a clinical study shown, that kidneys transplanted to diabetic patients exhibit light microscopic evidence of diabetic nephropathy (arteriolar hyalinisation) with in two years [10]. These patients have only one functioning kidney placed in a diabetic environment. Although it is not known exactly how long arteriolar hyalinisation takes to develop in diabetics it seems that its appearance in a transplanted kidney within two years, is significant. It thus seems, that diabetic nephropathy may progress more rapidly if the kidney is "forced" to hypertrophy.

Acknowledgements. This work was supported by a grant from the Danish Research Council. I am grateful to Mrs. Joan Hansen for her excellent technical assistance.

\section{References}

1. Ross, J., Goldman, J.K.: Effect of streptozotocin-induced diabetes on kidney weight and compensatory hypertrophy in the rat. Endocrinology 88, 1079-1082 (1971)

2. Seyer-Hansen, K.: Renal hypertrophy in streptozotocin-diabetic rats. Clin. Sci. Mol. Med. 51, 551-555 (1976)
3. Seyer-Hansen, K.: Renal hypertrophy in experimental diabetes: relation to severity of diabetes. Diabetologia 13, 141-143 (1977)

4. Munro, H. N., Fleck, A.: The determination of nucleic acids. Methods Biochem. Anal. 14, 113-176 (1966)

5. Burton, K.: A study of the conditions and mechanism of the diphenylamine reaction for the colorimetric estimation of deoxyribonucleic acid. Biochem. J. 62, 315-323 (1956)

6. Lowry, O.H., Rosebrough, N. J., Farr, A.L., Randall, R. J.: Protein measurement with the Folin phenol reagent. J. Biol. Chem. 193, 265-275 (1951)

7. Kurnick, N. B., Lindsay, P. A.: Nucleic acids in compensatory renal hypertrophy. Lab. Invest. 18, 700-708 (1968)

8. Preuss, H.G., Goldin, H.: A renotropic system in rats. J. Clin. Invest, 57, 94-101 (1976)

9. Mauer, S. M., Steffes, M. W., Brown, D. M.: Effects of reduction in renal mass on the glomerular lesions of diabetes mellitus in rats (Abstract). Diabetes 25 (suppl. 1), 349 (1976)

10. Mauer, S.M., Barbosa, J., Vernier, R.L., Kjellstrand, C.M., Buselmeier, T.J., Simmons, R. L., Najarian, J.S., Goetz, F.D.: Development of diabetic vascular lesions in normal kidneys transplanted into patients with diabetes mellitus. N. Engl. J. Med. 295, 916-920 (1978)

Received: November 21, 1977,

and in revised form: January 11, 1978

Dr. K. Seyer-Hansen

Department $\mathbf{M}$

Aarhus Kommunehospitalet

DK-8000 Aarhus C

Denmark 